\title{
Critical Role of Risk Management and its Impact on Bank Performance in Pakistan
}

\author{
DR.NISBAT ALI \\ Lecturer, National University of Modern Languages (NUML) \\ Islamabad (Pakistan) \\ nisbat.mna@gmail.com \\ DR. MUHAMMAD MAJID MAHMOOD BAGRAM \\ Assistant Professor, Department of Business Administration \\ Allama Iqbal Open University, Islamabad - Pakistan \\ HAIDAR ALI \\ PhD Scholar, Qurtuba University Peshawar Pakistan
}

\begin{abstract}
Risk management is most important factor to exist and survive for the financial industry. The major bankruptcies which incurred of ERON and Lehman-Brothers this arises the awareness about the appropriate risk management procedure in banking sectors. Our study analyze the various risk which can affect on banking operation in Pakistan and this study also include the effect of risk management on the performance of the large banking sector as well as small banking sectors in Pakistan. This study uses capital adequacy ratio, non performing loans, interest rate risk, liquidity risk and operational risk for the risk management. The data is taken from the published annual report of the commercial banks from 2005 to 2015. Descriptive statistics, correlation matrix and regression analysis use to analyze the data. This study leads to conclusion is that the better risk management system leads to the better performance of the banks. It's also conclude that capital adequacy ratio, non performing loans, interest rate risk, liquidity risk and operational risk that are key drivers of the profitability for the large banking sector of Pakistan. It's also tell us that only capital adequacy ratio and non performing loans are the key drivers of small banking sectors in Pakistan.
\end{abstract}

Key words: Risk Management, Commercial Bank, Capital Adequacy, Liquidity, Performance

\section{Introduction}

Financial institutions play an important role in the growth and the development of the country's economy. Banking sector considered one of the important sectors of financing most of the businesses. In past few decades has experienced many changes are made for managing to the banking industry due to large scale of bankruptcies in banking institution like Lehman-Brothers and Bear Stearns. The issues of risk management become most important fundamental in recent year. Risk Management is a process for the identification and assessment of loss liability encountered by a business entity adoption of applicable techniques to deal with the liability. 
Banking institution of Pakistan has encountered large number of risk such as liquidity risk, credit risk, foreign exchange risk, operation risk, interest rate risk and many other risks because of the unstable and volatile environment in the country. This study is first kind of the study which has been taken in to account the different risk face by the banks and their effect on bank performance using the relevant measures. This will contribute to fill the gap of exiting literature moreover the result of the study also indicates to what extend the risk effect the bank performance which may help the bank managers to take some steps to deal with measure of risk in order to improve the performance.

For keeping in mind the importance of risk management for banking sector this study address following objectives.

- To identify the major types of risks faced by the commercial banks in Pakistan.

- To determine the impact of risk management on the performance of large commercial banks and small commercial banks in Pakistan.

- Based on the findings of the study suggesting recommendations for the improvement of banking sector in Pakistan.

\section{Literature Review}

There a number of the studies are conducted to determinate the bank profitability. The study on the determinants of bank profitability began when Short (1979) studied the relationship between bank concentration and profit rate. Bourke (1989) extended the same study to twelve countries in North America, Europe and Australia. An effective and efficient risk management system is required for every banking sector to maximize the profitability. Effective risk management system enhances the performance of the any organization. On the other hand, Habib et al. (2014) studied the impact of operational risk management on bank performance in Pakistan. Their study concluded that risk management can enhance organizational performance while operational risk management is effective in the banking institutions of Pakistan.

\subsection{Liquidity Risk}

Liquidity risk one of the important determinate of the profitability. Liquidity risk arises because of a bank's inability to accommodate decrease in its liabilities or to increase the asset side of the balance sheet. Banks usually hold more liquid assets to avoid insolvency. But higher amounts of liquid assets are associated with lower rates of return; it is therefore assumed that higher liquid assets are associated with lower amounts of profitability.

\subsection{Credit Risk}

Cooper, Jackson and Patterson (2003) confirmed that fluctuations in credit risk bring changes in loan portfolios of banks which in return affect the bank performance. Duca and Mclaughlin (1990) found that increased exposure to credit risk by banks decreases their performance. Miller and Noulas (1997) also confirmed a negative relationship between bank's profitability and its credit risk as the more a bank is exposed to high risk loans, the probability of unpaid loans increases which ultimately decreases its profitability.

\subsection{Capital Adequacy Ratio}

Short (1979) provided evidence that size is associated with capital adequacy of banks and large banks are able to raise less expensive capital and produce higher rates of return as compared to small size banks. Akhavein, Berger \& Humphrey (1997) confirmed a 
positive relationship between profitability and bank size. Reynolds and Ratanakomut (2000) contributed that capital adequacy decreases with size, large banks have lower capital adequacy ratios as compared to small banks while profitability is directly related to capital adequacy of banks.

\subsection{Interest Rate}

Interest rate fluctuations are the major concern of the financial markets and institutions as it effects growth and performance. Decrease in the interest rate cause recession because increase in losses of loans and slower growth in loan. . Saunders \& Cornett (2003) concluded that interest rate shocks result in losses in the market value of assets which ultimately affects net worth. Also fall in the market value of assets and liabilities occurs when interest rate increase.

\subsection{Operational Risk}

Laker (2007) argued that increasing dependence on specialized skills technology and banking complexity has made operational risk an important risk factor as faced by banking institutions. Holmes (2003) contended that large amount of losses arises by the lack of operational risk management by banks. Wei (2006) asserted that announcement of operational losses by banks decrease their market values. The market value of assets and liabilities occurs when interest rate increases.

\subsection{Framework for the Study}

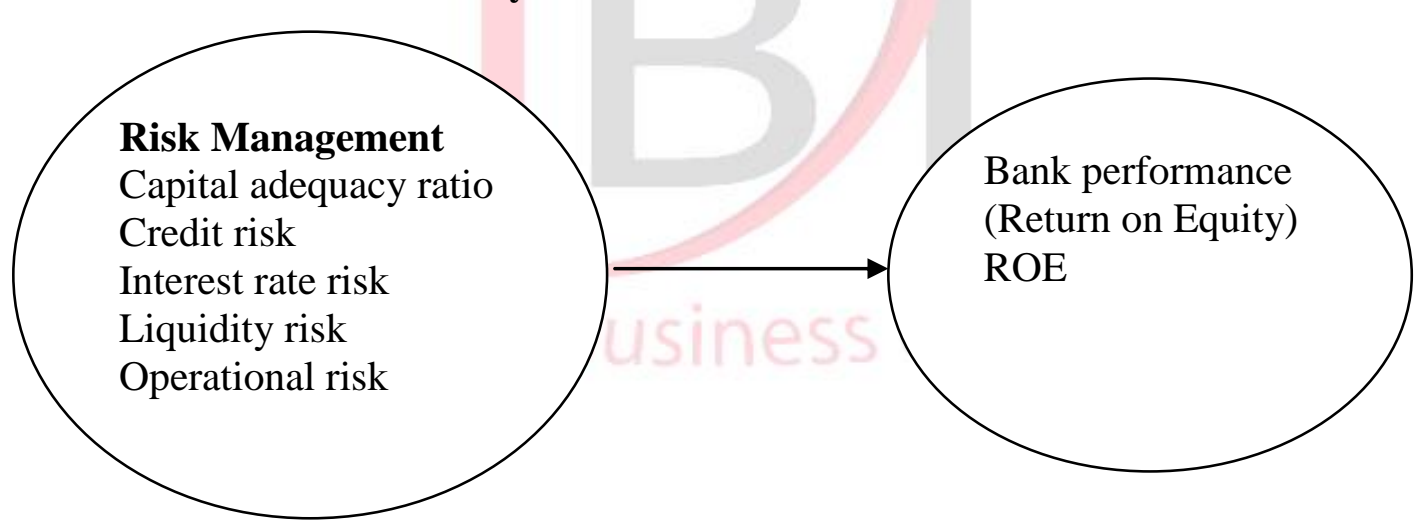

Frame work for Risk Management and Bank Performance in Pakistan.

\subsection{Hypotheses}

$H_{1}$ : There is a positive relationship between capital adequacy ratio and return on equity.

$\mathrm{H}_{2}$ : There is a negative relationship between credit risk (Non performing loans) and return on equity.

$H_{3}$ : There is a negative relationship between interest rate risk and return on equity.

$H_{4}$ : There is a negative relationship between liquidity risk and return on equity.

$H_{5}$ : There is a negative relationship between operational risk and return on equity. 
Table 1: Variables Descriptions

\begin{tabular}{|c|c|c|}
\hline S. No & Variables & Description \\
\hline 1 & $\begin{array}{l}\text { Return on equity } \\
\text { Bank performance }\end{array}$ & Measured by Net profit/Total equity \\
\hline 2 & Capital adequacy ratio & $\begin{array}{l}\text { Measured by total Capital/Risk } \\
\text { Weighted Assets }\end{array}$ \\
\hline 3 & Credit risk & $\begin{array}{l}\text { Measured by Non performing } \\
\text { loans/Total loans }\end{array}$ \\
\hline 4 & Interest rate risk & $\begin{array}{l}\text { Measured by Interest rate sensitive } \\
\text { assets/Total assets }\end{array}$ \\
\hline 5 & Liquidity risk & $\begin{array}{l}\text { Measured by Gross loans and } \\
\text { advances/Total deposits }\end{array}$ \\
\hline 6 & Operational risk & $\begin{array}{l}\text { Measured by Operating } \\
\text { expenses/Operating income }\end{array}$ \\
\hline
\end{tabular}

\section{Research Design and Methodology}

The objective of study is the certain impact of the risk management practices on the commercial bank of Pakistan. And also, comparison of the risk management and bank performance on the small and large commercial banks in Pakistan.

\subsection{Sample Size}

Our sample size is five small and five lager commercial banks are consider in our analysis. Banks having thousand and more than thousand branches consider as large banks on the other hand banks having less than thousand branches consider as small banks. According to the state bank of Pakistan statistic there are twenty seven large banks and twenty two are small but we only take five from twenty seven large banks and five from twenty two small banks. There are following five large banks which take in to our study these are National Bank of Pakistan (NBP), Habib Bank Limited (HBL), United Bank Limited (UBL), MCB Bank Limited and Allied Bank Limited these bank having more than thousand branches. Small commercial banks include Bank Alfalah Limited (BAL), Meezan Bank Limited (MBL), The Bank of Punjab (BOP), Faysal Bank Limited (FBL) and The Bank of Khyber (BOK).

Table 2: List of Selected Banks

\begin{tabular}{lllll}
\hline S.NO & Large Commercial Banks & Branches & Small Commercial Banks & Branches \\
\hline 1 & HBL & 1663 & BAL & 630 \\
2 & NBP & 1406 & MZL & 551 \\
3 & UBL & 1128 & BOP & 405 \\
4 & MCB & 1247 & FBL & 281 \\
\hline
\end{tabular}




\begin{tabular}{lllll}
\hline 5 & ABL & 1048 & BOK & 131
\end{tabular}

Source: State Bank of Pakistan (SBP) Website.

4. Result and Data Analysis

The data which is obtained from the sample banks were analyzed using descriptive statistics, correlation and regression analysis.

Table 3: Descriptive Statistics

Variables $\quad$ Small Banks $\quad$ Large Banks

\begin{tabular}{|c|c|c|c|c|c|c|c|c|}
\hline & Min & Max & Mean & SD & Min & Max & Mean & SD \\
\hline ROE & .07 & 1.37 & .1980 & .24994 & .00 & .30 & .1911 & .10024 \\
\hline CAR & 0.01 & .307 & 0.126 & .055 & .093 & .222 & .153 & .033 \\
\hline NPL & .06 & .51 & .2045 & .12782 & .07 & .18 & .1153 & .03506 \\
\hline IRR & .09 & .99 & .9133 & .17546 & 10 & .99 & .9004 & .17116 \\
\hline LTR & .46 & .78 & .5912 & .10958 & .31 & .72 & .5135 & .11673 \\
\hline ORS & .54 & 2.06 & .7490 & .29867 & .35 & .85 & .4916 & .10334 \\
\hline
\end{tabular}

Large Banks: National Bank of Pakistan (NBP), Habib Bank Limited (HBL), United Bank Limited (UBL), MCB Bank Limited and Allied Bank Limited

Small Banks: Bank Alfalah Limited (BAL), Meezan Bank Limited (MBL), The Bank of Punjab (BOP), Faysal Bank Limited (FBL) and The Bank of Khyber (BOK).

The above table shows the comparison of both small and large banks ROE. The minimum ROE for small banks is 0.07 and for large bank is 0.00 which indicate that the large banks earn zero profits on the other hand the small banks have not earned zero profits and losses for last five years of the study. The standard deviation of ROE for small banks is 0.24 and for large banks are 0.10 which show that there are lots of variations in the profitability of small banks than the larger banks. Capital adequacy ratio has shown stable situation for the both small and larger banks. The non performing loans are higher for small banks as compare to the larger banks and the maximum value and standard devotion are also higher of small banks as compare to the large banks. The interest rate risk, liquidity risk and operational risk for small banks higher on the other hand low for the larger banks and also means values and standard deviation for small banks comparatively higher and low for the large banks. 
Table 4: Correlation matrix for large banks

\begin{tabular}{|c|c|c|c|c|c|c|}
\hline Variables & ROE & CAR & NPL & IRR & LTR & ORS \\
\hline ROE & 1 & & & & & \\
\hline CAR & -0.313 & 1 & & & & \\
\hline NPL & -0.532 & 0.350 & 1 & & & \\
\hline IRR & 0.039 & 0.018 & 0.054 & 1 & & \\
\hline LTR & -0.346 & -0.128 & 0.059 & -0.232 & 1 & \\
\hline ORS & -0.685 & -0.225 & 0.547 & 0.037 & 0.245 & 1 \\
\hline \multicolumn{7}{|c|}{$\begin{array}{l}\text { Large Banks: National Bank of Pakistan (NBP), Habib Bank Limited (HBL), United } \\
\text { Bank Limited (UBL), MCB Bank Limited and Allied Bank Limited. } \\
\text { Table 5: Correlation matrix for small banks }\end{array}$} \\
\hline Variables & ROE & CAR & NPL & IRR & LTR & ORS \\
\hline ROE & 1 & & & & & \\
\hline CAR & -0.182 & 1 & & & & \\
\hline NPL & .541 & -0.427 & & & & \\
\hline IRR & -0.039 & 0.225 & -0.158 & 1 & & \\
\hline LTR & 0.107 & -0.493 & 0.157 & -0.044 & 1 & \\
\hline ORS & -0.112 & -0.424 & -0.031 & -0.926 & 0.172 & 1 \\
\hline
\end{tabular}

Small Banks: Bank Alfalah Limited (BAL), Meezan Bank Limited (MBL), The Bank of Punjab (BOP), Faysal Bank Limited (FBL) and The Bank of Khyber (BOK).

The above two tables show the correlation matrix of all independent and dependent variables of the study. The correlation matrix of large banks and large banks show that the correlation coefficients of the independent variables less than 0.80 , as suggested by Gujarati (2003). Therefore there is no problem of multiple correlation for large and as well as small banks.

\subsection{Regression Analysis}

Using ROE as dependent variable, this study on the set of hypothesis regarding the impact of risk on the bank performance of large and small commercial banks in Pakistan. The return on equity retrograde on capital adequacy ratio, non performing loans, interest rate risk, liquidity risk and operational risk. 
Large Banks: National Bank of Pakistan (NBP), Habib Bank Limited (HBL), United Bank Limited (UBL), MCB Bank Limited and Allied Bank Limited

Table 6: Regression Analysis for the Larger Banks

\begin{tabular}{|c|c|c|c|c|}
\hline Variables & Coefficients & $\begin{array}{l}\text { Standard } \\
\text { Error }\end{array}$ & T-Values & P-values \\
\hline Const & .716 & 0.79 & 9.051 & .000 \\
\hline CAR & .490 & .199 & 2.468 & .023 \\
\hline NPL & -1.478 & .343 & -4.304 & .000 \\
\hline IRR & -0.072 & 0.025 & -2.72 & 0.005 \\
\hline LTR & -2.08 & .075 & -2.773 & .012 \\
\hline ORS & -.389 & .114 & -3.339 & .003 \\
\hline \multicolumn{5}{|c|}{$\begin{array}{l}\text { R-Square }=87.03 \% \\
\text { Wald Chi }=57.20 \\
\text { Dependent Variable: ROE } \\
\text { The above table shows that capital adequacy ratio (CAR) has a positive significant } \\
\text { impact on performance (ROE) of large banks as the probability value } 0.00 \text { which is less } \\
\text { than 5\%. Other risk management variables of nonperforming loans (NPL), interest rate } \\
\text { risk (IRR), liquidity risk (LTR) and operational risk (ORS) are significantly and } \\
\text { negatively affecting the return on equity (ROE) for large commercial banks as the } \\
\text { probability values are less than 5\%. } \\
\text { 4.1 Regression Analysis of Small Banks } \\
\text { Small Banks: Bank Alfalah Limited (BAL), Meezan Bank Limited (MBL), The Bank of } \\
\text { Punjab (BOP), Faysal Bank Limited (FBL) and The Bank of Khyber (BOK). } \\
\text { Table 7:Regression Analysis for the Small Banks }\end{array}$} \\
\hline Variables & Coefficients & Standard Error & T-Values & P-values \\
\hline Const & 0.012 & 0.005 & 2.36 & 0.018 \\
\hline CAR & 0.01 & 0.00361 & 2.77 & 0.006 \\
\hline NPL & -0.011 & 0.005 & -2.38 & 0.017 \\
\hline IRR & -0.002 & 0.009 & -0.25 & 0.804 \\
\hline LTR & -0.04 & 0.161 & -0.09 & 0.928 \\
\hline
\end{tabular}




\begin{tabular}{lllll}
\hline ORS & 0.0006 & 0.0098 & 2.53 & 0.012
\end{tabular}

${ }^{-}$R-Square $=47.03 \%$

Wald Chi $=36.20$

Dependent Variable: ROE

The above table shows the regression results of risk management variables on performance of small commercial banks. The capital adequacy ratio (CAR) has a significant positive impact on ROE as the probability value is 0.006 which is less than $5 \%$ significant level. The impact of nonperforming loans (NPL) on ROE is negative and significant with a probability value of 0.017 . The impact of operational risk (ORS) on ROE is significant but positive with a probability value of 0.012 . While there is an with probability values of 0.804 and 0.928 respectively.

\subsection{Summary of Hypothesis Testing}

From the above test we do we analyze the hypothesis whether it's rejected or accepted on the basis of the result of descriptive statistics, correlation matrix and regression analysis.

The following table tells us or summarizes the result of the Hypothesis Testing.

Table 8: Summary of the tested Hypotheses

\begin{tabular}{|c|c|c|}
\hline 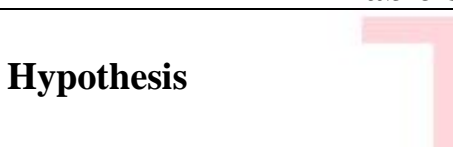 & $\begin{array}{l}\text { Large Banks } \\
\text { Coefficient Decision }\end{array}$ & $\begin{array}{l}\text { Small Banks } \\
\text { Coefficient Decision }\end{array}$ \\
\hline & SIGN & SIGN \\
\hline $\begin{array}{l}\mathrm{H} 1=\text { There is a positive } \\
\text { relationship between } \\
\text { capital adequacy ratio and } \\
\text { return on equity. } \\
\mathrm{H} 2=\text { There is a negative } \\
\text { relationship between credit } \\
\text { risk (Non performing } \\
\text { loans) and return on equity. }\end{array}$ & Accepted & Accepted \\
\hline $\begin{array}{l}\mathrm{H} 3=\text { There is a negative } \\
\text { relationship } \\
\text { interest rate risk and return } \\
\text { on equity. }\end{array}$ & Accepted & Rejected \\
\hline $\begin{array}{l}\mathrm{H} 4=\text { There is a negative } \\
\text { relationship } \\
\text { liquidity risk and return on } \\
\text { equity. }\end{array}$ & Accepted & Rejected \\
\hline
\end{tabular}




$\mathrm{H} 5=$ There is a negative
relationship $\begin{array}{r}\text { between } \\ \text { operational risk and return } \\ \text { on equity. }\end{array}$

\section{Limitations and Future Direction}

Basically our study on the banking sector of the Pakistan. Which cover the risks which cause threat to survive the banking sectors. And the result of the can help the banks management to overcome that risks. However our study can be implement on the others sectors to check what kind of the risk can affectthe organization performance. In our study due to unavailability of the data our sample size is small we do research on the selected banks so we suggest that the future research will be based on the large sample size in order to large extension of the result. And moreover other sectors consider in same approach the effects of performance. And other additional variables are taken to measure different risk and their effect on performance.

\subsection{Conclusion}

As we know that risk management is important in the development and the growth of the banking sector. And banking sector help in growth GDP of any country. The above result shows that the risk management effects the performance significantly. Capital adequacy ratio, nonperforming loans, liquidity risk, operational risk and interest rate risk all significantly affect and determine the profitability of large commercial banks in Pakistan. Therefore the lager banking sector have to concentrate on the quality of the loans and the procedure of the loans. And large banks also have concentrate on the liquidity position to avoid the liquidity crisis. The operating expense such as salaries of the employees and the administrative expenses. To reduce the shocks from interest rate risk, large banks should maintain such an amount of interest rate sensitive assets so that it can digest the fluctuations in interest rate. On the other hand capital adequacy ratio and credit risk affects the performance of the small commercial banks. So that the small commercial banks to maintain the required capital to meet the regulatory requirements and stable in to the market. The small commercials also have to focus on the quality of the loans and their distribution and evaluation procedure to remain stable in the market.

This study may have managerial and policy implication for the in the national and the international point of view. In the first it has supported by the Basel Accord of required capital in view of the positive relationship between capital adequacy and banks' profitability. Secondly, considering the negative relation between nonperforming loans and profit level, the also indicate the control of the non performing loans which is important issue of the banking sectors in national and the international context. And in the Pakistan the issue is more important in the banking history because of the large involvement of the politics which takes loan later on which converted in to non performing loans. That's why the banks are privatize for better control.

Thirdly there are negative effects of the interest rate on the profitability of the large commercial banks, the ups and downs in the interest should be given by the central bank for the better control of the interest rate in term of bank performance. This may advise to management of the banking sector to better anticipate the term of structure. The large 
banks have to maintain the regard of liquidity risk in order to support the findings that is this risk have negative effect on performance. At last the operational risk that also negatively affects the profitability and this may require to turn in to application of the sound businesses models control of the, processes and system to reduce to exposure operational risk under eye of the central bank or the and other world general bank and state bank of Pakistan in particular field and apply the relent rule and regulation for banking sector to reduce happening of these risk.

\section{References}

Akhavein, J. D., Berger, A.N. \& Humphrey, D.B. (1997). The effects of megamergers on efficiency and prices: Evidence from a bank profit function. Review of Industrial Organization, 12(1), 95-139

Alshatti, A. S. (2015). The effect of credit risk management on financial performance of the Jordanian commercial banks. Investment Management and Financial Innovations, 12(1), 338-345

Athanasoglou, P. P., Brissimis, S. N. \& Delis, M. D. (2008). Bank-specific, industry specific\& macroeconomic determinants of bank profitability. Journal of International Financial Markets, Institutions \& Money, 18(2), 121-136.

Bourke, P. (1989). Concentration and other determinants of bank profitability in Europe, North America and Australia. Journal of Banking \& Finance, 13(1), 65-79.

Carey, A. (2001). Effective risk management in financial institutions: the Turnbull approach. Balance Sheet, 9(3), 24-27.

Cooper, M. J., Jackson III, W.E. \& Patterson, G.A. (2003). Evidence of predictability in the cross-section of bank stock returns. Journal of Banking and Finance 27(5), 817-850.

Duca, J. \& McLaughlin, M. M. (1990). Developments affecting the profitability of commercial banks. Federal Reserve Bulletin 76(7), 477-499.

Gizaw, M., Matewos, K. \& Selvaraj, S. (2015). The impact of credit risk on profitability performance of commercial banks in Ethiopia. African Journal of Business Management, 9(2), 59-66.

Gujarati, D. (2003). Basic Econometrics (4th edn.). New York: McGraw Hill

Habib, S., Masood, H., Hassan, S. T., Mubin, M. \&Baig, U. (2014). Operational risk management in corporate and banking sector of Pakistan. Information and Knowledge Management, 4(5), 58-66.

Holmes, M. (2003). Measuring operational risk: A reality check. Risk, 16 (1), 84-87.

Iqbal, Z., \& Mirakhor, A. (2011). An Introduction to Islamic Finance: Theory and Practice. (2nd

Madura, J. (1989). Financial Markets and Institutions. New York. West Publishing Company.

Mathghamhna, S. N. (2011). Performance and Risk Management: Risk and Reward. Waters magazine, 03 October. Retrieved from. URL: www.Waterstechnology.com/waters /feature/ 2114023/feature-performancerisk management-risk-rewar 
Maxwell, O. O. \& Peter, E. G. (2016). Credit risk management and the performance of deposit money banks in Nigeria: An error correction analysis. Applied Economics and Finance, 3(2), 97-109.

Miller, S. \& Noulas, A. (1997). Portfolio mix and large-bank profitability in the USA. Applied Economics 29(4), 505-512.

Molyneux, P., \& Thornton, J. (1992). Determinants of European bank profitability: A note. Journal of Banking and Finance, 16(6), 1173-1178

Oluwafemi, A. S., Adebisi, A. N. S., Simeon, O., \& Olawale, O. (2013). Risk management and financial performance of banks in Nigeria. Journal of Business and Management, 14(6), 52-56.

Rejda, G. E. (2008). Principles of Risk Management and Insurance. (10th edn): Pearson Addison Wesley.

Reynolds, S. E. \& Ratanakomut, S.G. (2000). Bank financial structure in pre-crisis. East and South East Asia. Journal of Asian Economy, 11 (3), 319-331.

Saleem, S. \& Abideen, Zain-ul- (2011). Do effective risk management affect organizational performance. European Journal of Business and Management, 3(3), 258-267.

Saunders, A., \& Cornett, M. M. (2003). Financial Institutions Management; A Risk Management Approach. (4th edn). New York: McGraw-Hill/Irwin.

Selma, R. M., Abdelghani, E. \& Rajhi, M.T. (2011). Risk management tools practiced in Tunisian commercial banks. Studies in Business and Economics, 55-78.

Shafiq, A., \& Nasr, M. (2010). Risk management practices followed by the commercial banks in Short, B.K. (1979). The relation between commercial bank profit rates and banking concentration in Canada, Western Europe, and Japan. Journal of Banking and Finance 3(3), 209- 219.

Soyemi, K. A., Ogunleye, J. O. \& Ashogbon, F. O. (2014). Risk management practices and financial performance: evidence from the Nigerian deposit money banks (DMBs). The Business \& Management Review, 4(4), 345-354.

Uddin, M. H. (2009). Re-examination of stock liquidity risk with a relative measure. Studies in Economics and Finance, 26(1), 24-35.

Vaihekoskia, M. (2009). Pricing of liquidity risk: empirical evidence from Finland. Applied Financial Economics, 19(19) 1547-1557.

Wei, R. (2006). An empirical investigation of operational risk in the United States financial sectors. Working paper. The Wharton School, University of Pennsylvania, Philadelphia, PA.

$\mathrm{Yu}$, H. C. (2000). Banks' capital structure and the liquid asset-policy implication of Taiwan. Pacific Economic Review, 5(1), 109-114. 